\title{
EXPLORING PROPHETIC APPROACH OF DAWAH IN EDUCATION WITH RESPECT TO CONTEMPORARY APPLICATIONS
}

\section{Introduction}

All pioneers, reformers and history makers earned fame in one or two fields of life. It was the Holy Prophet (PBUH) who was a perfect and an exemplary model in all aspects of human life. Not only Muslims, but nonMuslims also acknowledged his expertise, skills, intelligence, wisdom, and strategy in peace as well as war affairs. Michael H. Hart said that "He was the only man in history who was supremely successful on both the religious and secular level". [Hart, 1978] G.B Shaw presented his tribute to our beloved Prophet Muhammad PBUH in the words that "he must be called the savior of humanity». [Farhat, 2019] The reason for the highness of Holy Prophet (PBUH) was that Allah Almighty itself proclaimed his prophet an exemplary model for humanity as it is referenced in Quran;

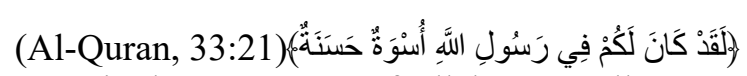

"There has certainly been for you in the Messenger of Allah an excellent pattern".

The claim of Noble Quran had been demonstrated hundred percent valid as he appeared as a reformer, an ideal personality, head of state, Judge, commander in chief, model trader, and a perfect educationist. In educational context, history affirms that the Holy Prophet (PBUH) was an enthusiastic teacher, wisest policy maker, well aware of educational objectives, well informed of teaching methodology, and a perfects preacher that's why he invested a large portion of time and energy in educational activities.

One of the motives of extraordinary emphasize on education was the first revelation of Noble Quran as Allah Almighty started his communication with our beloved Prophet PBUH with the 'education'. It was mentioned in the Surah Al-Alaq;

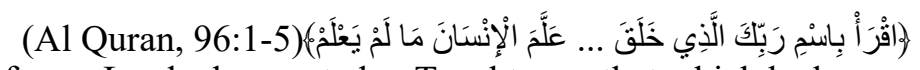

"Recite in the name of your Lord who created ...Taught man that which he knew not."

The Holy Prophet (PBUH) rehearsed this commandment of Holy Quran in a way that he never ignored a single opportunity of preaching through educational process. Additionally, we can see the life of Holy Prophet PBUH that he for an incredible duration accentuated Dawah activities throughout his life. The research shows that one of the essential duties of his Prophet Hood was to educate mankind. [Qureshi, S. A., \& Lodhi, 2011: 312]. The Noble Quran has depicted the four noteworthy obligations of our beloved Prophet Muhammad PBUH.

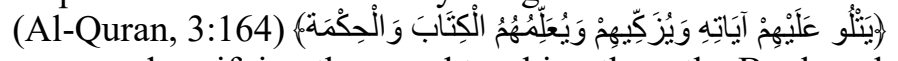

"Reciting to them His verses and purifying them and teaching them the Book and wisdom".

This verse of Noble Quran unmistakably uncovered the four obligations of Holy Prophet: first was recitation of Holy Quran, the second was purging heart from sins, the third was teaching Al-Qur'an, and the fourth was teaching wisdom. Each of these obligations rotated around the Dawah activities. It turned out to be clear by above lines the nothing was important than dawah in the eyes of our beloved Prophet PBUH.

One of the uniqueness of prophetic strategies was to make education as a source of preaching Dawah. There was no discrimination between worldly knowledge and religious knowledge. The Holy Prophet PBUH made special arrangements for Dawah which could be seen throughout his life. For this purpose he used the educational process as a tool of preaching the teachings of Islam. To convey the message of Islam, he went to the markets, fairs, gathering of people, heads of different tribes and utilized his ultimate potential to convince people towards the Islam and Allah Almighty. By having a look upon the strategy of Holy Prophet PBUH, the author intended to investigate the approach of Holy Prophet PBUH towards Dawah and its effectiveness in contemporary era. The research at one hand will disclose the prophetic methodology; while on the other hand would be beneficial to make the methodology of Dawah more effective and fruitful.

\section{Objectives of the study}

The main objectives of the study are:

1. To disclose the importance of education as a Dawah strategy of Holy Prophet BPUH.

2. To highlight the strategy of Holy Prophet PBUH in Dawah.

3. To explore the effectiveness of Prophetic strategy in contemporary times.

4. To make a bridge between theory and practice by suggesting possible solution. 


\section{Research Methodology}

The aim of this research paper was to explore the Holy prophet's PBUH strategy of preaching by education. Qualitative and descriptive research approach was employed. The author divided the research into two phases: first was descriptive in which author discussed the importance of education to Holy Prophet PBUH in the context of Dawah, second explored the strategy of Holy Prophet in Dawah which also dealt with the usability of Prophetic approach in contemporary times. For the collection of data, first of all Quran and Sunnah were consulted as primary sources and afterward books, theses, and biography of Prophet Muhammad PBUH were consulted as secondary sources. Some relevant material was also taken from internet after verification. Moreover, the author used the abductive reasoning by relating with the available literature in order to assess the ground realities and make the research applied and effective.

\section{Literature Review}

The Holy Prophet PBUH was sent to society of ignorant, illiterate, uncivilized and highly ill-mannered people. Their religious, political, social, economic, moral, cultural and educational condition was extremely depressed. Raghib Tabbakh writes about their educational condition that "one of major qualities of Arabs was to be Ummi (ignorant) as there were only few persons who could read and write." [Tabbakh, 2006]. Allah Almighty mentioned the ignorance of Arabs before sending the Holy Prophet PBUH;

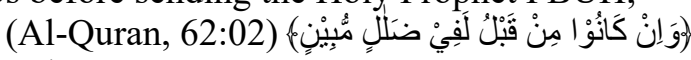

"Although they were before in clear error"

It was a great blessing of Allah to humanity that He sent His Prophet to take out the mankind from darkness towards light and rejoin the broken links between the creator and the creature. The Holy Prophet PBUH accomplished his mission with the help of Dawah and molded the men of ignorance into the men of knowledge. The consequences of prophetic reforms appeared in such a way that great scholars, intellectuals, men of letters, savants and sages were born among the unlettered people, and their knowledge, wisdom, sagacity and erudition was recognized by the entire world.

\section{Strategy of Holy Prophet PBUH in Dawah with Respect to Contemporary Applications}

There are many significant aspects of Dawah of Holy Prophet PBUH, out of which some are given below in the visual presentation and are discussed below in detail;

\section{Visual Presentation of Prophetic Strategy}

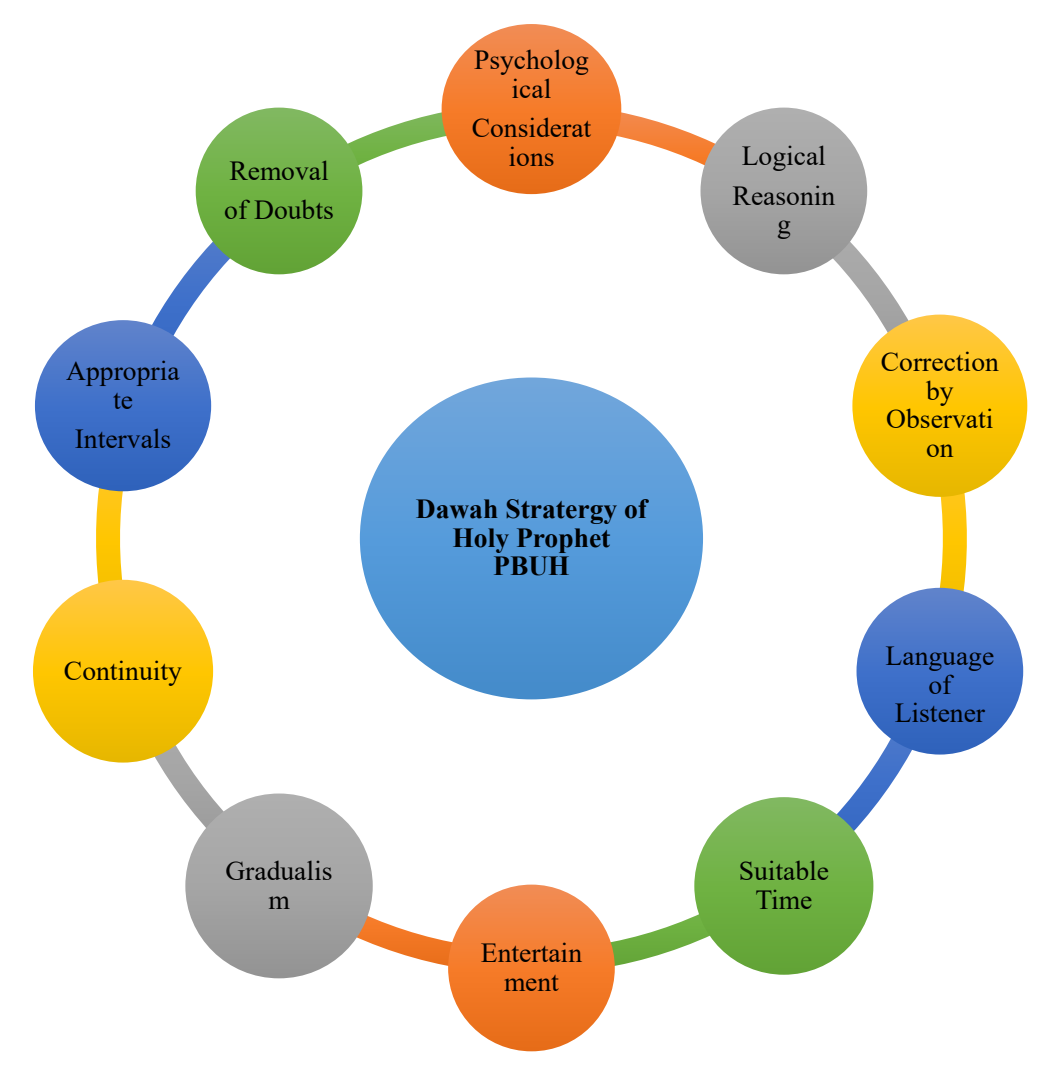




\section{Psychological Considerations in Dawah}

Addressing audience according to the audience's mental level is very important in dawah activities. To impress others, some people show off their knowledge by using difficult vocabs and sentences. In their caliber and natures, people are different. It is a God-gifted stuff, but the achievement is dependent upon everybody's comprehension.

Our Holy prophet PBUH talked with the companions in a way that they understood everything without any ambiguity. The companions belonged to different background including urban and rural. His methodology was equally beneficial for educated and uneducated individuals.

\section{Logical Reasoning \& Removal of Doubts in Dawah}

In dawah of Islamic injunctions, it is essential to have conceptual clarity. A clear mind can convey its message in logical and effective way. One can see the teachings of Islam that they are not blind like other religions. Islam asks time and again for logical reasoning and accepting things with reason and proof. Our Holy Prophet PBUH was well aware of objectives of shariah that why he used logical reasoning in his methodology". [Alkanderi, 2001: 101]

The methodology of Holy Prophet PBUH was very effective and listeners could easily understand and reach the objectives of injunctions. In fact, Our Holy Prophet PBUH was ordained by Allah Almighty to clearly convey the message of Islam as Holy Quran says about this feature of Holy Prophet PBUH:

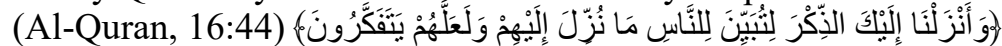

"And we revealed to you the message that you may make clear to the people what was sent down to them and that they might give thought".

\section{Correction by Observation}

The Prophetic way of correction of mistakes was wonderful. For instance, one narration is quoted below:

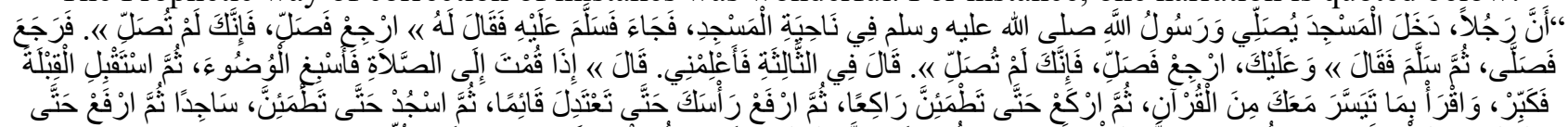

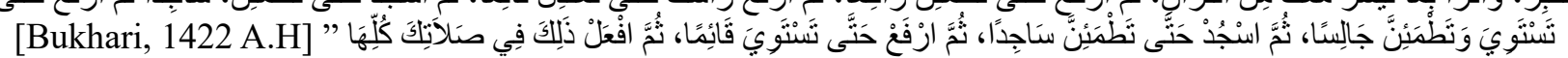

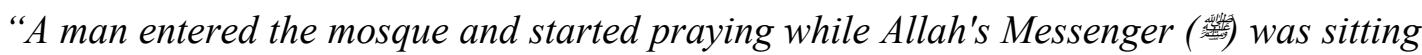
somewhere in the mosque. Then (after finishing the prayer) the man came to the Prophet (辣) and greeted him. The Prophet said to him, "Go back and pray, for you have not prayed. The man went back, and having prayed, he came and greeted the Prophet. The Prophet (4after returning his greetings said, "Go back and pray, for you did not pray." On the third time

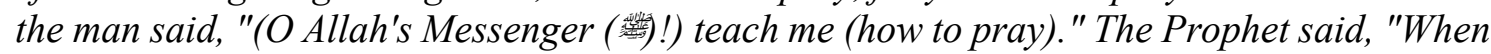
you get up for the prayer, perform the ablution properly and then face the Qibla and say Takbir (Allahu Akbar), and then recite of what you know of the Qur'an, and then bow, and remain in this state till you feel at rest in bowing, and then raise your head and stand straight; and then prostrate till you feel at rest in prostration, and then sit up till you feel at rest while sitting; and then prostrate again till you feel at rest in prostration; and then get up and stand straight, and do all this in all your prayers"

\section{Gradualism \& Continuity in Dawah}

Allah Almighty in the Holy Quran, ordained different obligations gradually. Various example could be seen in the Holy Quran in this regard. The gradual commandment of Zakat, Salah, and restriction of alcohol are clear instances of gradualism. Our Holy Prophet PBUH followed the same strategy of Quran and ordained his companions various injunctions by the principle of gradualism. He started preaching people by explaining the harms of incorrect beliefs, immoral habits, and bad quarrels then slowly, called people towards correct and sound thinking, worships, good morals and ethical values. [Alvi, 2005: 70]

Our Holy Prophet PBUH said in this regard:

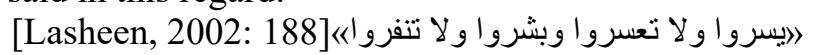

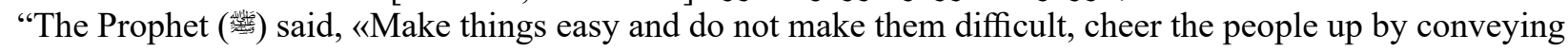
glad tidings to them and do not repulse (them)". 


\section{Language of Listener}

The medium of instructions in an educational system is very important because it produces long lasting effects on the understanding of students, academic learning and accomplishment of goals. It was the unique quality of holy Prophet PBUH that he used to teach by considering the language of the learners and using simple words which could easily be understood. It is reported into authentic narration that once a companion a person from a tribe came to Holy Prophet PBUH and he asked about fasting during travel. The Holy Prophet PBUH replied in his own language. In this context the preachers of Islam should consider the importance of language and try to use such language which could easily be understood by the listeners

\section{Suitable Time \& Appropriate Intervals for Preaching}

Along with other unique qualities the Holy Prophet PBUH was also a great psychologist. He was well aware that human mind cannot work continuously hours and hours that's why it could be seen in into the traditions of holy Prophet peace be upon him that he used to choose suitable time for preaching as well as make the pauses during his talk. It is reported into many ahadith that the holy Prophet used to take pauses during his talk that the listeners could count his words and receive his message very clearly. There was not any kind of ambiguity in his talk. The Islamic preachers should follow the strategy of our Prophet PBUH to convey the message of Islamic effectively.

\section{Entertainment in Dawah Activities}

It is the dilemma of our educational system that students don't show their interest into the learning activities and they get bore. The the strategy of holy Prophet peace be upon him was amazing in in a way that the students never got bore. Instead of losing interest, they were keenly interested to have more company with the Holy Prophet peace be upon him and spend their maximum time in the company of Holy Prophet peace be upon him.

\section{Giving Good News in Preaching}

One of the Unique qualities of Holy Prophet peace be upon him was giving good news during this teaching process. We could see in his traditions that he often used to give good news on good academic, moral and other achievements which led toward increase in productivity.

\section{Conclusions \& Recommendations}

The above points clearly revealed that the Holy Prophet PBUH was well aware of benefits of Psychological Considerations, Logical Reasoning, Removal of Doubts, Correction by Observation, Gradualism \& Continuity, Language of Listener, Suitable Time, Appropriate Intervals, Entertainment, Giving Company to the Companions, Giving Good News in Dawah. In this connection it would be beneficial for the religious scholars if they take guidance from the methodology of Holy Prophet PBUH in order to convey the messages of Islam in peaceful, effective, and comprehensive way. Moreover, the Islamic preachers should use all the contemporary means of preaching including electronic, print and social media and various other techniques to spread the message of Islam around the globe. By keeping in view, the prophetic strategy, the Islam will attract the both; believers and non-believers. Furthermore, the Prophetic principles would help in bringing peace and prosperity into the society.

\section{Bibliography:}

Alkanderi, L. (2011), Exploring Education in Islam: Al-Ghazali model of the Master-Pupil Relationship applied to educational relationships within the Islamic family, URL: https://latefah.net/artic3/EXPLORING_EDUCATION_IN_ ISLAM.pdf

Alvi, Dr. Khalid. (2005), Insan e Kanil (The Perfect Personality), Lahore, AL-Faisal Nashran, Ghazni Street, Urdu Bazaar, Lahore, Pakistan

Bukhari, Muhammad bin Ismail. (1422 A.H), Bukhari, Muhammad bin Ismail, Bairut, Dar Tuq unnajah.

Farhat, Amtul Q. (2019), The Non-Muslim verdict on Prophet Muhammad PBUH, The Muslim Times, URL: https:// themuslimtimes.info/2013/01/26/the-non-muslim-verdict-on-prophet-muhammad-pbuh

Hart, M. H. (1978), The 100: A Ranking of the Most Influential Persons in History, New York.

Lasheen, Musa Shaheen. (2002), Fathul Munim Shara Sahi Muslim, Cairo, Dar ulshurooq

Qureshi, S. A., \& Lodhi, M. I. (2011), Holy Prophet (PBUH) as a Preceptor for All Times, Dialogue, pp. 300-315.

Tabbakh, A. R. (2006), Tareekh-e-Afkar wa Uloom-e-Islami, Lahore, Islamic Publications. 


\title{
Muhammad Zulqarnain, Riaz Ahmad Saeed
}

\section{Exploring Prophetic Approach of Dawah in Education with Respect to Contemporary Applications}

Education holds a central position in the empowerment of society as it directly influences social, political, economic, and cultural system. It is beautified and dignified with sublime manifestations of its custodians (the teachers) who enlighten the globe by sound knowledge, professional conduct, moral values in terms of inspirational talk, sympathetic attitude, modesty, courage, wisdom, and truthfulness. The purpose of this paper is to investigate and explain the Dawah methodology of Holy Prophet PBUH in education. Qualitative and descriptive research approach was used for collection and analysis of data. The review of literature reveals that Holy Prophet (PBUH) considered education as a change agent in society as he wisely inculcated importance of education in the illiterate tribal society. He by using effective teaching methods conveyed the peaceful message of Islam, built strong positive relationship with people and preached them by showing sympathy, humbleness, patience and modesty. The article in this context is divided into two parts; first would address the significant of education to Prophet Muhammad PBUH in context of Dawah, second would address the strategy of Holy Prophet PBUH in Dawah and its usefulness for contemporary preachers. The research concluded that Holy Prophet PBUH has established a relationship with the audience of reverence, self-esteem, grace, courtesy and kindness. To an ordinary people he was very kind and soft-hearted. First, in front of the public he himself showed good deeds and then urged them to carry on his teachings. He proved to be a respectful, modest and soft-hearted preacher throughout his life. This was the reason that his perfect model of teaching changed the ignorant Bedouin society in a short span of time and as the Quran purports, brought them from darkness to light.

\section{Мухаммад Зулькарнайн, Ріаз Ахмад Саӥд}

\section{Дослідження пророчого підходу Дават в освіті з повагою до сучасних впроваджсень}

Освіта займає центральне місце в розширенні можливостей суспільства, оскільки вона безпосередньо впливає на соціальну, політичну, економічну та культурну систему. Це допомагає прикрашувати через гідні прояви своїх зберігачів (викладачів), які просвітлюють земну кулю знаннями, професійною поведінкою, моральними иінностями з точки зору натхненної розмови, співчутливого ставлення, скромності, мужності, мудрості та правдивості. Мета даної роботи - дослідити та пояснити методику Дават Святого Пророка (мир йому) у навчанні. Для збору та аналізу даних використовувався якісний та описовий підхід дослідження. Огляд літератури показує, щьо Святий Пророк (мир йому) розглядав освіту як агент змін у суспільстві, оскільки він мудро придавав значення освіті в неграмотному племінному суспільстві. Він, використовуючи ефективні методи навчання, передавши мирне послання ісламу, вибудував міцні позитивні стосунки з людьми та проповідував серед них, проявляючи співчуття, смиренність, терпіння та скромність. В иььму контексті стаття поділена на дві частини; перша звернеться до освіти у розумінн пророка Мухаммеда (мир йому) у контексті Дават, друга - до стратегї Священного Пророка (мир йому) у Дават та корисності ї̈ для сучасних проповідників. У дослідженні було зроблено висновк, щчо Святий Пророк (мир йому) встановив стосунки зі слухачами через пошану, самоповагу, благодать, ввічливість та доброту. До звичайного народу він був дуже добрим і лагідним. Спериу перед громадськістю він сам показав добрі справи, а потім закликав їх продовжувати його вчення. Він проявив себе шанобливим, скромним і м'якосердим проповідником протягом усього життя. Це було причиною того, шяо його досконала модель навчання за короткий проміжок часу змінила неосвічене бедуїнське суспільство $i$, як вважає Коран, вивело їх з темряви до світла.

\author{
Dr. Muhammad Zulqarnain \\ Former Principal, Al-Ghazali School of Excellence, Wah Cantt, Pakistan \\ zulqarnain4386@gmail.com+92 3074386143
}

\section{Dr. Riaz Ahmad Saeed}

Lecturer, Dept. of Islamic Studies, National University of Modern Languages, Pakistan 